\title{
Kalp Yetersizliği Hastalarında Öz Bakımı Değerlendirme ve Etkileyen Risk Faktörlerin Belirlenmesi
}

 \\ Fatmanur Özdemir, ${ }^{1}$ (1) Ömer Faruk Enez ${ }^{1}$ \\ ${ }^{1}$ Marmara Üniversitesi Sağlık Bilimleri Fakültesi, Hemşirelik Bölümü, İstanbul \\ 2ìstanbul Gelişim Üniversitesi Sağlık Bilimleri Yüksekokulu, Hemşirelik Bölümü, İstanbul
}

\begin{abstract}
Özet
Amaç: Bu araştırmada kalp yetersizliği hastalarında öz bakımı değerlendirme ve etkileyen faktörlerin belirlenmesi amaçlandı.

Yöntemler: Araştırma tanımlayıcı ve kesitsel nitelikte olup bir eğitim ve araştırma hastanesinde gerçekleşti. Bu araştırmanın evreni Aralık 2017-Mayıs 2018 tarihleri arasında çalışmanın yapıldığı hastanenin kardiyoloji kliniklerinde yatan kalp yetersizliği tanısı almış tüm hastalar, örneklemini ise Aralık 2017 Mayıs 2018 tarihleri arasında kardiyoloji kliniklerinde yatmakta olan 210 hasta oluşturdu. Verilerin toplanmasında Tanımlayıcı Anket Formu ve Avrupa Kalp Yetersizliği Öz Bakım Davranış Ölçeği kullanıldı. Tanımlayıcı Anket Formu toplam 15 sorudan oluşmaktadır. Avrupa Kalp Yetersizliği Öz Bakım Davranış Ölçeği Jaarsma ve arkadaşları tarafından 2003 yılında geliştirilmiş, Baydemir ve arkadaşları tarafından 2013 yılında ölçeğin Türkçe geçerlik, güvenirliği yapılmıştır. Ölçek 5 likert tipi olan 12 maddeden oluşmaktadır. Ölçeğin total puanı 12-60 arası değişmekte olup, 12-36 puan öz bakım davranışının uygun ve 37-60 arası puan öz bakım davranışının yetersiz olduğunu göstermektedir. Veriler yüzdelik, ki kare testi kullanılarak değerlendirildi. Bulgular: Bu çalışmada yaşlı olan hastaların ve obez hastaların öz bakım davranışlarının yetersiz olduğu belirlendi (sırasıyla; $p=0.000, p=0.003$ ). Eğitim durumu ortaöğretim, lise ve üniversite olanların, sigara kullanmayanların ve kronik hastalığı olmayanların öz bakım davranışlarının yeterli olduğu saptandı (sırasıyla; $p=0.000, p=0.000, p=0.026$ ). Çalışmamıza göre Avrupa Kalp Yetersizliği Öz Bakım Davranışı Ölçeği'nden alınan toplam puanlara bakıldığında minimum değer 14; maksimum değer 53; ortalama değer ise 30.57 olduğu bulundu.
\end{abstract}

Sonuç: Bu çalışmada genel olarak hastaların öz bakım davranışlarının orta seviyede olduğu belirlendi. Yaşlılık, obezite, sigara kullanma ve kronik hastalık varlığı öz bakımı olumsuz yönde etkileyen faktörler arasında yer almaktadır.

Anahtar sözcükler: Hemşirelik; kalp yetersizliği; öz bakım.

\section{Assessment of Self-Care in Heart Failure Patients and Determination of RiskFactors Affecting}

\section{Abstract}

Objective: In this study, it was aimed to determine self care behaviours in heart failure patients.

Methods: The study was descriptive and cross sectional in nature and was conducted in a training and research hospital. The study population consisted of all patients with heart failure diagnosed in cardiology clinics of the hospital between

\footnotetext{
İletişim (Correspondence): Hmş. Gülay Yıldırım. İstanbul Gelişim Üniversitesi Sağlık Bilimleri Yüksekokulu, Hemşirelik Bölümü, İstanbul, Turkey Telefon (Phone): +90 2124227000 E-Posta (E-mail): gulayyldrm@yahoo.com
} 


\begin{abstract}
December 2017 and May 2018 and 210 sample of whom were in cardiology clinics between December 2017 and May 2018. Descriptive Questionnaire Form and The European Heart Failure Self Care Behavior Scale were used to collect data. The questionnaire consists of 15 questions in total. The European Heart Failure Self Care Behavior Scale was developed by Jaarsma et al. in 2003, and validity and reliability of the scale were determined by Baydemir et al. in 2013. The scale consists of 12 items of 5 Likert type. The total score of your scale ranged from 12 to 60 , indicating that self care behaviors of 12-36 points were appropriate and self care behaviors of 37-60 points were inadequate. Data were evaluated using percentage, chi-square test. Results: It was determined that the self care behaviors of elderly patients and obese patients were inadequate in this study $(p=0.001, p=0.01$ respectively).It was found that self care behaviors of those with secondary education, high school and university education, non smokers and non chronic ones were sufficient ( $p=0.001, p=0.001, p=0.05$ respectively). Based on the total scores of the The European Heart Failure Self Care Behavior Scale, the minimum score is 14; maximum 53; mean value was found to be 30.57 .

Conclusion: In this study, it was determined that the patients' self care behaviors were in the middle level. Self care behaviors fall in the presence of old age, obesity, smoking and chronic illness.

Keywords: Nursing; heart failure; self care.
\end{abstract}

Cite this article as: Bayrak B, Yıldırm G, Oğuz S, Sağaltıcı Ç, Doğanay E, Özdemir F, et al. Assessment of Self-Care in Heart Failure Patients and Determination of Risk Factors Affecting. Turk J Cardiovasc Nurs 2019;10(23):114-121.

$K^{2}$ alp yetersizliği, kalbin dokuların ihtiyaç duyduğu kanı yeterli pompalayamaması ya da bunu ancak yüksek kardiyak dolum basınçları ile sağlayabilen ciddi kronik bir hastalıktır. ${ }^{[1]}$ Bu hastalık yaşlı popülasyonun artması ile giderek artmaktadır. Kalp yetersizliği prevelansının 2012'den 2030'a kadar \%46 artacağı tahmin edilmektedir. ${ }^{[2]}$ Türkiye'de kalp yetersizliği ile ilgili yapılan epidemiyolojik çalışmada kalp yetersizliği prevelansı \%2.9'dur. Ülkemizde erişkin kalp yetersizliği genç nüfusta daha fazla görülmekte ve prevelansı batılı ülkelerden çok daha yüksek seyretmektedir. ${ }^{[3]}$ Kalp yetersizliği prevelansı ve mortalitesi yüksek aynı zamanda klinik bulguları ağır seyreden bir hastalıktır. Hastalığın klink bulgularında; pulmoner yataktaki kan göllenmesine bağlı dispne, kaslara kan akımının azalması sonucu yorgunluk görülür. Pulmonerlerde kan göllenmesi önce interstisyel ödeme sonrasında pulmoner ödeme yol açar. Hasta bu dönemde kuru öksürük, düz yatma sebebiyle venöz dönüşün artması ve pulmoner basıncın yükselmesi ile uykudan uyandıran proksismal noktürnal dispne yaşar. Kalbin sağ ventrikül yetersizliğine bağı boyun venlerinde dolgunluk, hepatomegali ve abdominal distansiyon görülür. ${ }^{[4,5]}$ Görülen fizyolojik sorunların beraberinde hastanın üretkenliği azalır. Hasta psikososyal ve ekonomik yönden sorunlar yaşar. ${ }^{[6]}$ Bu sebeplerden dolayı kalp yetersizliği hastalarında yaşam kalitesi bozulur. ${ }^{[7]}$

Öz bakım, hastalıkla ilgili semptomlar ortaya çıktığında hastanın baş edebilmek için ne yapabileceğine karar verebilmesi, başkalarına bağımlı olmadan, kendi sağlığının sorumluluğunu alabilmesidir. ${ }^{[8]}$ Tanı konulduktan sonra yaşam kalitesini sürdürmede hastanın öz bakımını karşılayabilmesi önemlidir. Kessing ve ark., ${ }^{[7]}$ öz bakımın yaşam kalitesi ile ilişkili olduğunu ve depresyon ile anksiyetenin bu ilişkiyi etkilediğini saptamışlardır. Hasta da öz bakımın yetersiz olması anksiyeteyi artırabilir ve tedaviyi olumsuz yönde etkileyebilir. Hastanın öz bakımının yeterli olması kalp yetersizliği tedavisinin önemli bir parçasını oluşturur. Hemşire hasta da öz bakımı değerlendirebilmeli, öz bakımı etkileyen faktörleri belirleyebilmeli ve öz bakım davranışlarını oluşturabilmelidir. Hemşirenin hastada yeterli öz bakımı sağlayabilmesi hastanın anksiyetesini azaltmada, tedavinin olumlu sonuçlar vermesinde, hastaneye yatışları ve hastalığın ekonomik yükünü azaltmada etkin bir yöntem olacaktır. ${ }^{[9-12]}$ Kronik kalp yetersizliği olan hastaların hastaneye yeniden yatışlarının incelendiği bir çalışmada diyete uyum ile hastaneye yeniden yatışlar arasında ilişki olmadığı, sadece diyete değil, bütün olarak hastalığın yönetimine uyum gösterilirse, hastaneye yeniden yatışların azalabileceği vurgulanmıştır. ${ }^{[13]}$ Aynı zamanda hemşirenin hasta da öz bakım davranışlarını oluşturması farmakolojik olmayan bir yöntemdir. Kalp yetersizliğinin tedavisinde öz bakım, hastane yatışlarını, ekonomik yükü azaltan farmakolojik olmayan bir yöntem olarak kullanılabilir. Hastada öz bakım davranışlarını oluşturmada hemşirenin öz bakımı etkileyen faktörleri belirleyebilmesi ve öz bakımı değerlendirebilmesi önemlidir.

Bu çalışmanın amacı kalp yetersizliği hastalarında öz bakımı değerlendirme ve etkileyen faktörleri belirleyebilmektir.

\section{Gereç ve Yöntem}

\section{Araştırmanın tipi ve amacı}

Araştırma tanımlayıcı ve kesitsel nitelikte olup kalp yetersizliği hastalarında öz bakımı ve etkileyen faktörlerin belirlenmesi amacıyla yapıldı.

\section{Araştırmanın yeri ve zamanı}

Araştırma bir eğitim ve araştırma hastanesinde 30 Aralık 2017- 30 Mayıs 2018 tarihleri arasında Marmara Üniversitesi Sağlık Bilimleri Enstitüsü Klinik Araştırmalar Etik Kurulu'n- 
dan (Onay Tarihi ve Sayısı: 06.11.2017-217) etik kurulu izni ve kurum izni alınarak gerçekleştirildi. Araştırma, Helsinki Deklerasyonu Prensipleri'ne ve “iyi klinik uygulamalar kılavuzu" nda belirtilen esaslar ilkesine uygun olarak yürütüldü.

\section{Araştırmanın evren ve örneklemi}

Bu araştırmanın evreni Aralık 2017- Mayıs 2018 tarihleri arasında bir eğitim ve araştırma hastanesinin kardiyoloji kliniklerinde yatan kalp yetersizliği tanısı almış tüm hastalar, örneklemi ise bu tarihler arasında bir eğitim ve araştırma hastanesinin kardiyoloji kliniklerinde yatan 210 hasta oluşturdu. Benzer bir çalışma ele alınarak yapılan power analizi sonucunda tespit edilen örneklem sayısı 200 hastadır.

Araştırmada aşağıdaki sorulara yanıt aranmaktadır:

- Kalp yetersizliği hastalarının öz bakım davranışları yeterli midir?

- Kalp yetersizliği hastalarına ait sosyodemografik özellikler hastaların öz bakımlarını etkiler mi?

\section{Veri Toplama Araçları}

Araştırmanın verileri Tanımlayıcı Bilgi Formu ve Avrupa Kalp Yetersizliği Öz Bakım Davranış Ölçeği ile toplandı.

\section{Tanımlayıcı Bilgi Formu}

Araştırmacılar tarafından hastaların demografik özelliklerini tanımlamak amacıyla hazırlanan 15 maddelik (yaş, cinsiyet, medeni durum, kilo, boy, eğitim durumu, meslek, gelir durumu, sağlık güvencesi, ek bir kronik hastalık varlığı, kalp yetersizliği için kullanılan ilaçlar, sigara içme durumu, alkol kullanma durumu) bir formdur.

\section{Avrupa Kalp Yetersizliği Öz Bakım Davranış Ölçeği}

Jaarsma ve arkadaşları tarafından 2003 yılında geliştirilmiş, Baydemir ve arkadaşları tarafından 2013 yılında Türkçeye uyarlanarak ölçeğin geçerlik, güvenirlik ve tutarlığı test edilmiştir. ${ }^{[14,15]}$ Ölçeğin iç tutarlılığı 0.69 olarak bulunmuştur. Bu çalışmada cronbach alfa katsayısı 0,66 olarak bulundu. Ölçek 4 alt faktör ve 12 maddeden oluşmaktadır. Bu 4 alt faktör; tedaviye uygunluk, faaliyetlere uyma, tavsiyelere bağlııık ve yardım almaktır. Bu ölçek kalp yetersizliğine ilişkin ödem, nefes darlığı, yorgunluk gibi semptomları tanılamayı; bu semptomlara yönelik ilaçların düzenli kullanılmasını, sıvı ve tuz alımını, diyet ve egzersiz düzenlemesini içeren toplam 12 sorudan oluşmaktadır. Ölçeğin puanlamasında likert tipi ölçek (1-5 arası) kullanıımıştır. Her bir madde 1'den 5'e kadar puanlanmaktadır (1 tamamen katılıyorum, 2 kısmen katılıyorum, 3 ne katılıyorum ne de katılmıyorum, 4 kısmen katılmıyorum ve 5 hiçbir şekilde katılmıyorum). Ölçeğin total puanı 12-60 arası değişmekte olup, 12-36 puan öz bakım davranışının uygun ve 37-60 arası puan öz bakım davranışının yetersiz olduğunu göstermektedir.

\section{Veri toplanma yöntemi}

Verileri toplamaya başlamadan önce çalışmaya katılmayı kabul eden hastalardan bilgilendirilmiş gönüllü olur formuyla yazılı izin alındı. Hastalar ile uygun fiziki koşullarda birebir yapılan görüşmelerde Tanımlayıcı Bilgi Formu ve Avrupa Kalp Yetersizliği Öz Bakım Davranış Ölçeği kullanılarak veriler toplandı. Anket ve ölçek soruları hastaların verdiği cevaplar doğrultusunda araştırmacılar tarafından dolduruldu. Görüşmeler yaklaşık 5-10 dakika sürdü.

\section{Verilerin değerlendirmesi}

Hastaların sosyodemogrofik özelliklerinin değerlendirilmesinde yüzdelik hesaplama kullanıldı. Yeterli ve yetersiz öz bakımı olan hasta grupları ile bu hastaların sosyodemografik özellikleri arasındaki fark ki kare testi ile değerlendirildi. Anlamlılık değeri $\mathrm{p}<0.05$ olarak ele alındı.

\section{Araştırmanın Etik Yönü}

Avrupa Kalp Yetersizliği Öz Bakım Davranış Ölçeği için Doç. Dr. Canan Baydemir'den e-mail aracılığıyla izin alındı.

Çalışmanın yapılması için gerekli kurum izni alındı, araştırmaya katılan kişilerin kimlik bilgileri alınmadı, araştırmaya katılan hastaların sözlü ve yazılı onamları alındı.

\section{Çalışmaya Alınma Kriterleri}

- Kalp Yetersizliği tanısı almış olmak,

- 18 yaşından büyük olmak,

- Araştırmaya katılmayı engelleyecek herhangi bir iletişim sorunu (görme bozukluğu, işitmede azalma, Türkçeyi anlama/konuşabilmede yetersizlik, psikiyatrik/doğumsal bozukluk) olmaması,

- Araştırma ile ilgili açıklama yapıldıktan sonra çalışmaya katılmaya istekli olmak.

\section{Çalışmadan Çıkarılma Kriterleri}

- Araştırmaya katıldıktan sonra herhangi bir sebeple araştırmadan çıkma talebinde bulunan hastalar

\section{Bulgular}

Çalışmaya katılan hastaların \%53.3'ü 36-53 yaş grubunda, \%84.3'ü erkek, \%84.8'i evli, \%49'u fazla kilolu, \%38.1'i ilköğretim mezunu, \%40' ımekli, \%50.5'inin geliri giderine eşit, \%99'nun sağlık güvencesi bulunmakta, \%91.4'ü sigara kullanmıyor, \%98,1'i alkol kullanmıyor, \%70'i kronik hastalığa sahiptir. Kronik hastalığı olanların \%57.6'sı hipertansiyon, \%39'u diyabet, \%6.2'si kronik böbrek yetersizliği, \%4.8'i astım, \%3.3'ü KOAH, \%1.9'u anemidir (Tablo 1). 


\begin{tabular}{|c|c|c|}
\hline Özellikler & $\mathbf{n}$ & $\%$ \\
\hline \multicolumn{3}{|l|}{ Yaş } \\
\hline $18-35$ & 16 & 7.6 \\
\hline $36-53$ & 112 & 53.3 \\
\hline $54-71$ & 63 & 30 \\
\hline 72 ve üzeri & 19 & 9 \\
\hline \multicolumn{3}{|l|}{ Cinsiyet } \\
\hline Kadın & 33 & 15.7 \\
\hline Erkek & 177 & 84.3 \\
\hline \multicolumn{3}{|l|}{ Medeni durum } \\
\hline Bekar & 32 & 15.2 \\
\hline Evli & 178 & 84.8 \\
\hline \multicolumn{3}{|l|}{ Beden Kitle İndeksi (BKI) } \\
\hline$\leq 18,5$ (Zayıf) & 5 & 2.5 \\
\hline 18.6-24.99 (Normal) & 61 & 29.0 \\
\hline 25-29.99 (Fazla kilolu) & 103 & 49.0 \\
\hline$\geq 30$ (Obez) & 41 & 19.5 \\
\hline \multicolumn{3}{|l|}{ Eğitim durumu } \\
\hline Okuryazar değil & 10 & 4.8 \\
\hline Okuryazar & 7 & 3.3 \\
\hline İlköğretim & 80 & 38.1 \\
\hline Ortaöğretim & 19 & 9.0 \\
\hline Lise & 44 & 21.0 \\
\hline Üniversite ve/veya üstü & 50 & 23.8 \\
\hline \multicolumn{3}{|l|}{ Meslek } \\
\hline Emekli & 84 & 40.0 \\
\hline Serbest meslek & 72 & 34.3 \\
\hline Memur & 21 & 10.0 \\
\hline Ev hanımı & 28 & 13.3 \\
\hline Çalışmıyor & 5 & 2.4 \\
\hline \multicolumn{3}{|l|}{ Gelir düzeyi } \\
\hline Gelir giderden çok & 12 & 5.7 \\
\hline Gelir gidere eşit & 106 & 50.5 \\
\hline Gelir giderden az & 92 & 43.8 \\
\hline \multicolumn{3}{|l|}{ Sağlık güvencesi } \\
\hline Var & 208 & 99.0 \\
\hline Yok & 2 & 1.0 \\
\hline \multicolumn{3}{|l|}{ Sigara kullanımı } \\
\hline Var & 18 & 8.6 \\
\hline Yok & 192 & 91.4 \\
\hline \multicolumn{3}{|l|}{ Alkol kullanımı } \\
\hline Var & 4 & 1.9 \\
\hline Yok & 206 & 98.1 \\
\hline \multicolumn{3}{|l|}{ Kronik hastalık } \\
\hline Var & 147 & 70.0 \\
\hline Yok & 63 & 30.0 \\
\hline \multicolumn{3}{|l|}{ Hipertansiyon } \\
\hline Var & 121 & 57.6 \\
\hline Yok & 89 & 42.4 \\
\hline \multicolumn{3}{|l|}{ Diyabet } \\
\hline Var & 82 & 39.0 \\
\hline Yok & 128 & 61.0 \\
\hline \multicolumn{3}{|l|}{ Kronik böbrek yetersizliği } \\
\hline Var & 13 & 6.2 \\
\hline Yok & 197 & 93.8 \\
\hline \multicolumn{3}{|l|}{ Astım } \\
\hline Var & 10 & 4.8 \\
\hline Yok & 200 & 95.2 \\
\hline $\mathrm{KOAH}$ & & \\
\hline Var & 7 & 3.3 \\
\hline Yok & 203 & 96.7 \\
\hline Anemi & & \\
\hline Var & 4 & 1.9 \\
\hline Yok & 206 & 98.1 \\
\hline Toplam & 210 & 100 \\
\hline
\end{tabular}

\begin{tabular}{|c|c|c|}
\hline İlaçlar & $\mathbf{n}$ & $\%$ \\
\hline \multicolumn{3}{|c|}{ Antitrombotik } \\
\hline Evet & 178 & 84.8 \\
\hline Hayır & 32 & 15.2 \\
\hline \multicolumn{3}{|l|}{ Diüretik } \\
\hline Evet & 115 & 54.8 \\
\hline Hayır & 95 & 45.2 \\
\hline \multicolumn{3}{|c|}{ Antiaritmik } \\
\hline Evet & 114 & 54.3 \\
\hline Hayır & 96 & 45.7 \\
\hline \multicolumn{3}{|c|}{ Dijital grubu } \\
\hline Evet & 101 & 48.1 \\
\hline Hayır & 109 & 51.9 \\
\hline \multicolumn{3}{|c|}{ Oral antidiyabetik } \\
\hline Evet & 77 & 36.7 \\
\hline Hayır & 133 & 63.3 \\
\hline \multicolumn{3}{|c|}{ ACE inhibitörü } \\
\hline Evet & 59 & 28.1 \\
\hline Hayır & 151 & 71.9 \\
\hline \multicolumn{3}{|c|}{ Antihipertansif } \\
\hline Evet & 53 & 25.2 \\
\hline Hayır & 157 & 74.8 \\
\hline \multicolumn{3}{|c|}{ Antidepresan } \\
\hline Evet & 36 & 17.1 \\
\hline Hayır & 174 & 82.9 \\
\hline \multicolumn{3}{|c|}{ Betabloker } \\
\hline Evet & 29 & 13.8 \\
\hline Hayır & 181 & 86.2 \\
\hline \multicolumn{3}{|c|}{ Antikoagülan } \\
\hline Evet & 21 & 10.0 \\
\hline Hayır & 189 & 90.0 \\
\hline \multicolumn{3}{|c|}{ Vazodilatör } \\
\hline Evet & 19 & 9.0 \\
\hline Hayır & 191 & 91.0 \\
\hline \multicolumn{3}{|c|}{ Kolesterol ilacı } \\
\hline Evet & 14 & 6.7 \\
\hline Hayır & 196 & 93.3 \\
\hline Toplam & 210 & 100 \\
\hline
\end{tabular}

Çalışmaya katılan kalp yetersizliği hastalarında en sık kullanılan ilaçlar \%84.8 ile antitrombotik, \%54.8 ile diüretik ve \%54.3 ile antiaritmik ilaçlardır (Tablo 2).

Yaş grubu ile öz bakım davranışı karşılaştırıldığında 72 ve üzeri yaş grubu hastaların diğer yaş grubundaki hastalara göre öz bakım davranışlarının yetersiz olduğu ve aralarında istatistiksel olarak anlamlı bir farklılık olduğu belirlendi $(\mathrm{p}<0.001)$ (Tablo 3).

Beden Kitle İndeksi obez olan hastaların öz bakım davranışları zayıf, normal ve fazla kilolu olan hastaların öz bakım davranışlarına göre daha yetersiz olduğu ve BKi'i sınıflaması ile öz bakım davranışı arasında istatistiksel olarak anlamlı 


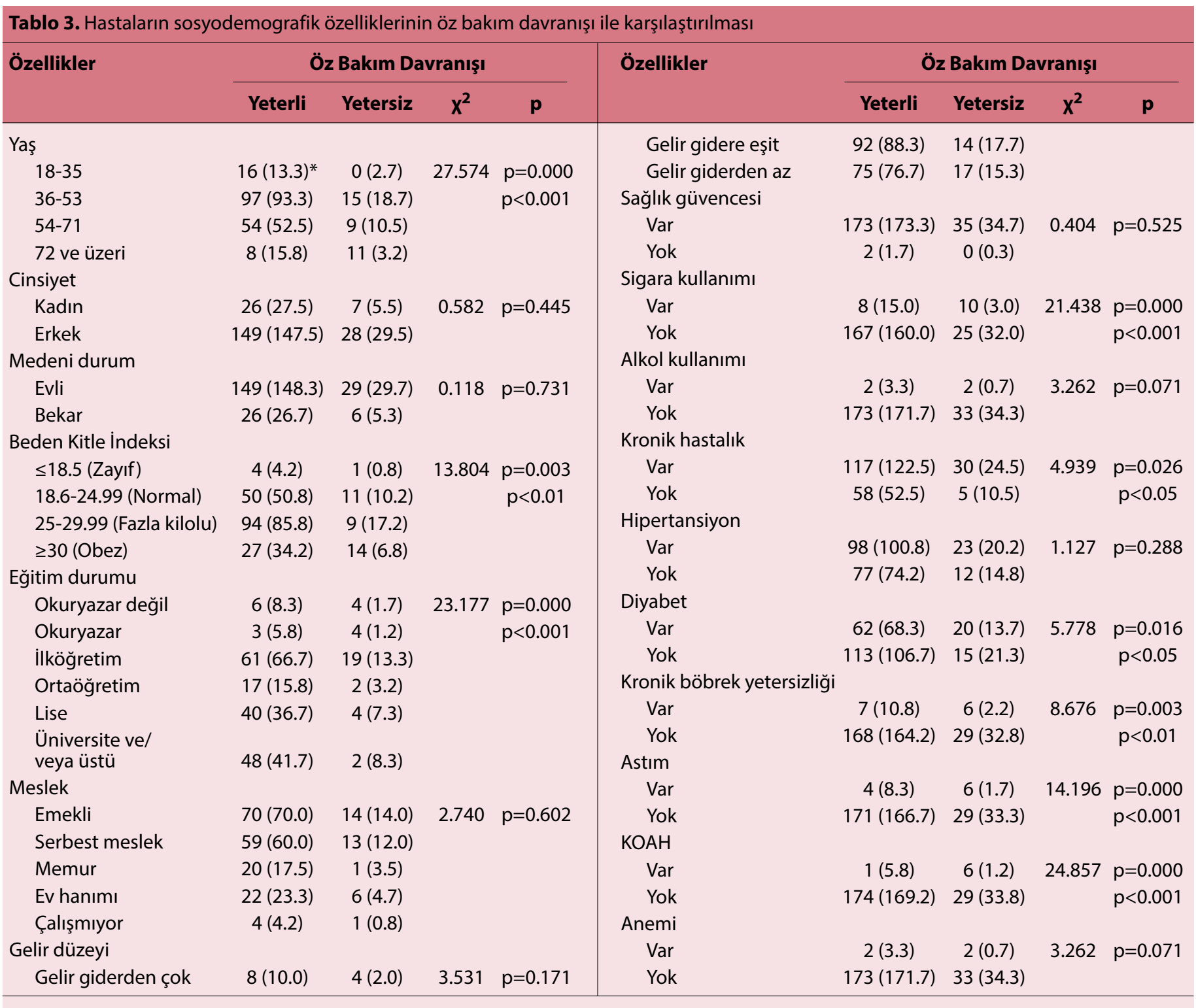

Not: *Parantez içerisindeki veriler beklenen değerlerdir.

bir farklılık olduğu saptandı ( $p<0.01$ ) (Tablo 3).

Okur yazar olmayan, okur yazar ve ilköğretim mezunu olan hastaların öz bakım davranışları ortaöğretim, lise, üniversite ve üstü olan hastaların öz bakım davranışlarına göre daha yetersiz olduğu ve eğitim durumu ile öz bakım davranışları arasında anlamlı bir farklılık olduğu belirlendi $(p<0.001)$ (Tablo 3).

Sigara kullanan hastaların öz bakım davranışları sigara kullanmayan hastaların öz bakım davranışlarına göre daha yetersiz olduğu ve sigara kullanma durumu ile öz bakım davranışları arasında anlamlı bir farklııık olduğu görüldü $(p<0.001)$ (Tablo 3).

Kronik hastalığı olanların öz bakım davranışları kronik hastalığı olmayanların öz bakım davranışlarına göre daha ye- tersiz olduğu ve değişkenler arasında anlamlı bir farklııı olduğu belirlendi $(p<0.05)$ (Tablo 3 ).

Kronik hastalık olarak diyabeti olan hastaların öz bakım davranışları diyabeti olmayanlara göre yetersizdi. Hastada diyabet varlığı ve öz bakım davranışları arasında anlamlı farklılık olduğu tespit edildi ( $p<0.05$ ) (Tablo 3).

Kronik hastalık olarak kronik böbrek yetersizliği olan hastaların öz bakım davranışları kronik böbrek yetersizliği olmayanlara göre yetersizdi. Hastada kronik böbrek yetersizliği varlığı ile öz bakım davranışları arasında anlamlı farklııı olduğu belirlendi $(p<0.01)$ (Tablo 3 ).

Kronik hastalık olarak astımı olan hastaların öz bakım davranışları, astımı olmayanlara göre yetersizdi. Hastada astımın varlığı ile öz bakım davranışları arasında anlamlı farklı- 


\begin{tabular}{|c|c|c|c|c|}
\hline Sorular & Ort. & \pm SS & Min. & Maks. \\
\hline Her gün tartılırım & 2.64 & 1.3 & 1 & 5 \\
\hline Solunum sıkıntım (nefes darlığım) olursa, onu rahatlatacak şekilde davranırım (adımlarımı yavaşlatmak, dinlenmek) & 2.01 & 1.0 & 1 & 5 \\
\hline Solunum sıkıntım (nefes darlığım) artarsa, hekimi veya hemşiremi ararım & 2.68 & 1.4 & 1 & 5 \\
\hline Ayaklarım/bacaklarım normalden fazla şişerse hekimi veya hemşiremi ararım & 2.93 & 1.5 & 1 & 5 \\
\hline Eğer bir hafta içinde iki kilo alırsam (ağırlaşırsam, kazanırsam), hekimi veya hemşiremi ararım & 3.48 & 1.4 & 1 & 5 \\
\hline İçtiğim sıvı miktarını kısıtlarım (günde 1,5-2 litreden fazla olmamak üzere). & 2.41 & 1.3 & 1 & 5 \\
\hline Gün içinde dinlenirim & 1.78 & 0.8 & 1 & 5 \\
\hline Yorgunluğumun arttığını hissedersem hekimi veya hemşiremi ararım & 3.28 & 1.4 & 1 & 5 \\
\hline Az tuzlu bir diyetle (yiyeceklerle) beslenirim & 1.87 & 1.1 & 1 & 5 \\
\hline İlaçlarımı önerildiği şekilde alıım & 1.15 & 0.6 & 1 & 5 \\
\hline Her yıl grip aşısı olurum & 3.46 & 1.6 & 1 & 5 \\
\hline Düzenli egzersiz yaparım & 2.90 & 1.4 & 1 & 5 \\
\hline Toplam ölçek puanı & 30.58 & 7.1 & 14 & 53 \\
\hline
\end{tabular}

Ort: ortalama; SS: standart sapma; Min.: minumum; Maks.: maksimum.

lık olduğu görüldü $(p<0.001)$ (Tablo 3).

Kronik hastalık olarak KOAH olan hastaların öz bakım davranışları KOAH olmayanlara göre yetersizdi. Hastada KOAH varlığı ile öz bakım davranışları arasında anlamlı farklılık olduğu belirlendi $(p<0.01)$ (Tablo 3 ).

Hastaların cinsiyet, medeni durum, mesleği, gelir düzeyi ve sosyal güvencesi ile öz bakım davranışları arasında anlamlı bir farklılık saptanmadı ( $p>0.05$ ).

Kronik hastalık olarak hipertansiyon veya anemisi olan hastaların olmayanlara göre öz bakım davranışları arasında anlamlı bir farklılık görülmedi ( $p>0.05$ ).

Kalp yetersizliği hastalarının Avrupa Kalp Yetersizliği Öz Bakım Davranış Ölçeği sorularına verdikleri cevaplar incelendiğinde; en düşük ortalamayı “ilaçlarımı önerildiği şekilde alırım (1.15 \pm 0.6$)$ sorusu, en yüksek ortalamayı ise "Eğer bir hafta içinde iki kilo alırsam, hekimi veya hemşiremi ararım

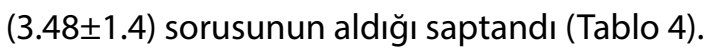

Araştırmada, Avrupa Kalp Yetersizliği Öz Bakım Davranış Ölçeği'nden alınan toplam puanlara bakıldığında minimum değer 14, maksimum değer 53, ortalama değer ise 30.58 \pm 7.1 olarak bulundu (Tablo 4).

\section{Tartışma}

Kalp yetersizliği hastalarının semptomlarla baş edebilmesi ve sağlık davranışları geliştirebilmesi hastalığın etkili kontrolünü sağlayacaktır. Hemşirelerin hastada etkili bir öz bakım davranışı geliştirebilmede etkin bir rolü bulunmaktadır. Etkili öz bakım kalp yetersizliği hastalığında; tedaviye katkıda bulunan, hastanın yaşam kalitesini artıran, tekrarlı yatışları ve ekonomik yükü azaltan farmakolojik olmayan bir yöntemdir. Bu sebeple kalp yetersizliği hastalarında öz bakımı değer- lendirme ve etkileyen faktörlerin belirlenmesi önemlidir.

Araştırma da 72 ve üzeri yaş grubu hastaların diğer yaş grubundaki hastalara göre öz bakım davranışlarının yetersiz olduğu belirlendi $(p<0.001)$ (Tablo 3). Prochota ve ark. ${ }^{[16]}$ öz bakım ile yaş arasında anlamlı bir korelasyon olduğunu; yaş arttıkça öz bakım davranışlarının azaldığını saptamışlardır. Kalp yetersizliği olan yaşlı erişkinlerde bilişsel eksiklikler ve öz bakım davranışlarının incelendiği başka bir çalışmada da ileri yaşın kötü öz bakım ile ilişkili olduğu bulunmuştur. [17] İnsanlar yaş ilerledikçe fiziksel ve psikososyal değişimler yaşar. Yaşa bağlı gelişen fonksiyonel (görme, işitme kaybı gibi) ve zihinsel işlev yetersizlikleri öz bakımın gerçekleştirilmesinde sorunlar oluşturabilir. Yaşlı hastalarda öz bakım davranışlarının yetersiz olması bu sebeplere bağlı olabilir.

Beden Kitle İndeksi obez olan hastaların öz bakım davranışları zayıf, normal ve fazla kilolu olan hastaların öz bakım davranışlarına göre yetersizdi $(p<0.01)$ (Tablo 3$)$. Kessing ve ark. ${ }^{[7]}$ kronik kalp yetersizliği olan hastalarda öz bakım ve yaşam kalitesi ile ilgili yaptıkları çalışmada, BKi yüksek olan hastaların daha az olumlu sağlık davranışları sergilediklerini tespit etmişlerdir. Kalp yetersizliği hastalarında obezite hastalık belirtilerinin daha ağır seyretmesine yol açabilir. Hareket kısıtlılığı ve günlük aktivitelerini yerine getirirken daha çabuk yorulma, nefes darlığının çekilmesi bu hastaların öz bakım davranışlarını yerine getirmede zorlanmalarına yol açmış olabilir.

Okur yazar olmayan, okur yazar ve ilköğretim mezunu olan hastaların öz bakım davranışları ortaöğretim, lise, üniversite ve üstü olan hastaların öz bakım davranışlarına göre yetersizdi $(p<0.001)$ (Tablo 3). Kessing ve ark. (2017) ${ }^{[7]}$ yaptıkları çalışmada, eğitim düzeyi düşük olan hastaların öz bakımlarının da yetersiz olduğunu saptamışlardır. Kalp 
yetersizliği hastalarında hastaya ait özelliklerin (yaş, eğitim, sosyal destek, eşlik eden hastalık gibi) öz bakıma etkilerinin incelendiği çalışmada da araştırmacılar çoklu regresyon analizi ile oluşturdukları yedi değişkenli modelin öz bakımla ilişkisini incelemiş ve sadece eğitim ve semptom şiddeti değişkenlerinin öz bakıma anlamlı katkı yaptığını bulmuşlardır. ${ }^{[18]}$ Kalp yetersizliği hastalarında ev ziyaretleri programı yaparak öz bakım davranışlarının incelediği başka bir çalışmada eğitim düzeyi yüksek olan hastaların daha iyi öz bakım davranışı gösterdiği saptanmıştır. ${ }^{[19]}$ Eğitim düzeyinin artmasıyla sağlık okur yazarlığı da artar. Böylelikle birey, günlük yaşam örüntüleri ile sağlığına ilişkin davranışları arasında eğitim düzeyi düşük olanlara göre daha kolay bağlantı kurabilir. Bu noktadan hareketle gelişime ve değişime açık olan eğitim düzeyi yüksek bireyler, sağlık ile ilgili bilinçlidir ve öz bakımları yüksek olabilir.

Sigara kullanan hastaların öz bakım davranışları sigara kullanmayan hastaların öz bakım davranışlarına göre yetersizdi $(p<0.001)$ (Tablo 3). Sigara akciğerleri etkileyen, solunum yolu hastalıklarına yol açan ve hastayı kansere kadar götürebilen kötü bir alışkanlıktır. ${ }^{[20]}$ Genç yetişkinlerde risk oluşturan yaşam tarzı ve davranışlarının farkındalığını oluşturmada kardiyovasküler hastalıkların risk faktörlerinin bilinmesi önemlidir. Oğuz ve arkadaşlarının yaptığı çalışmada üniversite öğrencilerinin kardiyovasküler risk faktörleri bilgi düzeylerinin yüksek olduğu saptanmıştır. Kardiyovasküler risk faktörleri bilgi düzeyinin yüksek olması bireylerin yaşam biçimi ve davranışlarına etki etmektedir. ${ }^{[21]}$ Öz bakım davranışlarını oluşturmanın temelinde; bireyin sağlığını ve iyilik durumunu sürdürmek için başlattığı ve gerçekleştirdiği etkinlikler yer alır. Sigara kullanımı öz bakım davranışlarını oluşturabilme ile bağdaşmayan bir durumdur. Araştırma da sigara kullananların öz bakım davranışlarının yetersiz olması beklenen bir sonuç olarak yorumlanabilir.

Kronik hastalığı olanların öz bakım davranışları kronik hastalığı olmayanlara göre daha yetersizdi $(p<0.05)$ (Tablo 3). Çalışma da kronik hastalık olarak diyabeti, kronik böbrek yetersizliği, astım ve KOAH'sı olan hastaların öz bakım davranışlarının yetersiz olduğu saptandı (sıarsıyla; $p<0.05$, $\mathrm{p}<0.01, \mathrm{p}<0.001, \mathrm{p}<0.01$ ) (Tablo 3). Buck ve ark., ${ }^{[22]}$ kalp yetersizliği hastalarında eşlik eden kronik hastalıkların öz bakım davranışlarına ve hastaların hastane yatışları ile yaşam kalitelerine etkilerini incelemişler ve çalışma da, eşlik eden hastalıkların fazlalığının yetersiz öz bakıma sebep olduğunu bulmuşlardır. Başka bir çalışma da diyabet ve kalp yetersizliği hastalarında öz bakımın yetersiz olduğu saptanmıştır. ${ }^{[23]}$ Diyabet, $\mathrm{KOAH}$, kronik kalp yetersizliği ve böbrek yetersizliği hastalıklarından herhangi birini taşıyan 1154 hastanın öz yönetimi uygulamada yetersiz olduğu belirlenmiştir. ${ }^{[24]}$ ìki ya da daha fazla kronik hastalığın varlığı bireylerde ağrı, yorgunluk gibi semptomların daha sık tekrarlanmasına yol açabilir, çoklu ilaç kullanımı sebebiyle tedaviye uyumu zorlaştırabilir. ${ }^{[25]} \mathrm{Bu}$ araştırmada kronik hastalıkların varlığının hastalarda çoklu ilaç kullanımına sebep olduğu için hastaların tedavisine uyumunu olumsuz etkilediği ve öz bakım davranışlarında yetersizliğe yol açtığı düşünülmektedir.

Araştırmada ölçekten alınan puanlar 14-53 arası değişmektedir. Öz bakım ölçeğinden alınan ortalama değer $30.58 \pm 7.1$ 'dir (Tablo 4). Ölçekten alınan puanların yüksek olması öz bakımın yetersiz olduğunu göstermektedir. Bu araştırmada hastaların öz bakım davranışları orta düzeydedir. Kalp yetersizliği hastalarında öz bakım ve yaşam kalitesinin değerlendirildiği bir çalışmada da hastaların öz bakım davranışları orta düzeyde bulunmuştur. ${ }^{[26]}$ Avrupa Kalp Yetersizliği Öz Bakım Davranış Ölçeği'nin psikometrik özelliklerine ilişkin yapılmış çalışmaların analiz edildiği başka bir çalışmada da öz bakım ölçeğinden alınan ortalama puanların 24-34 aralığında olduğu ve hastaların sıklıkla bu öz bakım davranışlarını uygulayabildikleri saptanmıştır. ${ }^{[27]}$ Türkiye'de öz bakım davranışlarının incelendiği çalışmalarda kalp yetersizliği hastalarında öz bakımın yetersiz olduğu bulunmuştur. $^{[8,6]}$ Yine ülkemizde yapılan başka bir çalışmada da öz bakım gücü toplam puan ortalaması 106.03 \pm 16.51 bulunmuş ve öz bakım gücünün iyi düzeyde olduğu tespit edilmiştir. ${ }^{[5]}$ Ülkemizde ve diğer ülkelerde yapılan çalışmalar incelendiğinde öz bakım değerlendirilmesinde farklı sonuçlara rastlanmıştır. Bu durumun toplumsal yapı ve kültürel farklııklardan kaynaklandığı düşünülmektedir. Ülkemizde yapılan çalışmalarda farklı sonuçlara rastlanması ise sosyodemografik verilerin farklılık göstermesi ve öz bakımı etkileyen faktörlerin etkin rol oynaması sebep olabilir. Aynı zamanda ülkemizde kardiyovasküler hastalığı olan bireylerin biyolojik, psikolojik ve sosyal sağlığının korunmasında etkili olan, hastalık sonrası yaşam biçimi değişikliklerine hastanın uyumunu sağlayan kardiyak rehabilitasyon istenilen düzeye ulaşmamıştır. ${ }^{[28]}$ Buna bağlı olarak da hastaların öz bakım davranışlarında yetersizlikler görülmüş olabilir.

\section{Sonuç}

Sonuç olarak, kalp yetersizliği hastalarının öz bakım davranışlarının orta düzeyde olduğu belirlendi. Yaş, obezite, eğitim durumu, sigara kullanımı ve kronik hastalık varlığının öz bakımı olumsuz etkilediği saptandı. Öz bakımı etkileyen faktörlerden birini veya bir kaçını taşıyan hastalarda öz bakım gücünü arttıııı destek sistemler geliştirilebilir. Aynı zaman da kalp yetersizliği hastalarında öz bakımı etkileyen faktörler ile ilgili daha geniş çalışmalar yapılması önerilmektedir. 
Etik Kurul Onayı: Marmara Üniversitesi Sağlık Bilimleri Enstitüsü Klinik Araştırmalar Etik Kurulu'ndan (Onay Tarihi ve Sayısı: 06.11.2017-217) etik kurulu izni ve kurum izni alınarak gerçekleştirildi.

Hakem Değerlendirmesi: Dış bağımsız.

Çıkar Çatışması: Yazarlar arasında herhangi bir çıkar çatışması bulunmamaktadır.

Yazarlık Katkıları: Konsept: S.O., B.B.; Dizayn: S.O., B.B.; Veri Toplama veya İşleme: Ç.S., E.D., F.Ö., Ö.F.E; Analiz ve Yorumlama: G.Y.; Literatür Arama: G.Y.; Yazan: S.O., G.Y.

\section{Kaynaklar}

1. Enç N, Öz Alkan H. Kronik Kalp Yetersizliği Hastalarının Hastane İçi Hemşirelik Bakımı. Kardiyovasküler Hemşirelik Dergisi 2012;3(4):85-100.

2. Go AS et al. Heart disease and stroke statistics - 2014 update. Circulation 2014;129:28-292.

3. Değertekin $M$, ve ark. Türkiye'deki Kalp Yertersizliği Prevelansı ve Öngördücüleri: HAPPY Çalışması. Türk Kardiyol Dern Arş 2012;40(4):298-308.

4. Inamdar AA, Inamdar AC. Heart Failure: Diagnosis, Management and Utilization. J Clin Med 2016;5(62):2-28.

5. Ermiş N, Kasar Sayın K, Karaman E, Yıldırım Y. Kronik Kalp Yetersizliği Olan Hastalarda Öz Bakım Gücü ve Yorgunluk. Turk J Cardiovasc Nurs 2018;9(20):105-112.

6. Akbıyık A, Koçak G, Oksel E. Kronik Kalp Yetmezliği Olan Hastalarda Öz-Bakım Davranışlarının İncelenmesi. İzmir Kâtip Çelebi Üniversitesi Sağlık Bilimleri Fakültesi Dergisi 2016;1(2):1-8.

7. Kessing D, Denollet J, Widdershoven J, Kupper N. Self-care and Health-Related Quality of Life in Chronic Heart Failure: A Longitudinal Analysis. European Journal of Cardiovascular Nursing 2017;16(7):605-613.

8. Asgar Pour H, Gökçe S, Kunter D, Yönem H. Kalp Yetersizliği Olan Hastalarda Öz Bakım Davranışlarının Değerlendirilmesi. F N Hem Derg 2016;24(2):66-71.

9. Müller-Tasch $M$ ve ark. Anxiety and Self-Care Behaviour in Patients With Chronic Systolic Heart Failure: A Multivariate Model. European Journal of Cardiovascular Nursing 2018;17(2):170-177.

10. Akmal Shafie A, Ping Tan Y, Hui Ng C. Systematic Review of Economic Burden of Heart Failure. Heart Fail Rev 2018;23(1):131145.

11. Chlalup Linn A, Azzolin K, Nogueira de Souza E. Association Between Self-Care and Hospital Readmissions of Patients with Heart Failure. Rev Bras Enferm 2016;69(3):469-74.

12. Oguz S, Enç N, Yiğit Z. Kronik Kalp Yetersizliği olan hastalar için inanç ve uyum ölçeklerinin Türkçeye Uyarlanması. Türk Kardiyol Dern Arş 2010;38(7):480-485.

13. Sönmez E, Oğuz S. Kronik Kalp Yetersizliği Olan Hastaların Hastaneye Yeniden Yatışları ile Diyete Uyumları Arasında- ki İlişki. Turkiye Klinikleri J Intern Med Nurs-Special Topics 2016;2(3):23-29.

14. Jaarsma T, Strömberg A, Martenson J, Dracup K. Development and Testing of the Europen Heart Failure Self- Care Behaviour Scale. Euro Heart Fail 2003;5(1):363-370.

15. Baydemir C, Özdamar K, Ünalır A. Validity of the Turkish Version of the European Heart Failure Self-Care Behavior Scale. Anadolu Kardiyol Derg 2013;13(1):573-9.

16. Prochota B, Szwamel K, Uchmanowicz I. Socio-clinical Variables Affecting the Level of Self-Care in Elderly Patients with Heart Failure. Eur J Cardiovasc Nurs 2019;18(7):628-636.

17. Uchmanowicz I, Jankowska-Polańska B, Mazur G, Sivarajan Froelicher E. Cognitive Deficits and Self-Care Behaviors in Elderly Adults with Heart Failure. Clinical Interventions in Aging 2017;12(1):1565-1572.

18. Rockwell JM, Riegel B, Michigan L. Predictors of Self-Care in Persons with Heart Failure. Heart \& Lung 2001;30(1):18-25

19. Trojahn MM et al. Predictors of Better Self-Care in Patients with Heart Failure after Six Months of Follow-Up Home Visits. Nursing Research and Practice 2013;1-5.

20. Oğuz S, Çamcı G, Kazan M. Üniversite Öğrencilerinin Sigara Kullanım Sıklığı ve Sigaranın Neden Olduğu Hastalıkları Bilme Durumu. Van Tıp Derg 2018;25(3):332-337.

21. Oğuz S, Erguvan B, Ünal G, Bayrak B, Çamcı G. Üniversite Öğrencilerinde Kardiyovasküler Hastalıklar Risk Faktörleri Bilgi Düzeyinin Belirlenmesi. MN Kardiyoloji 2019;26(3):184-191.

22. Buck HG et al. Predictors of Hospitalization and Quality of Life in Heart Failure: A Model of Comorbidity Self-Efficacy and Self-Care. H.G. International Journal of Nursing Studies 2015; 52(1):1714-1722.

23. Ausili $D$ et al. Clinical and socio-demodraphic Determinants of Self-Care Behaviours in Patients with Heart Failure and Diabetes Mellitus: A Multicentre Cross-sectional Study. International Journal of Nursing Studies 2016;63(1):18-27.

24. Bos-Touwen I et al. Patient and Disease Characteristics Associated with Activation for Self Management in Patients with Diabetes, Chronic Obstructive Pulmonary Disease, Chronic Heart Failure and Chronic Renal Disease: A Cross Sectional Survey Study. Plos One 2015;7:1-15.

25. Kalender N, Sütçü Çiçek H, Kronik Hastalıkların Yönetimindeki Engeller. Turkiye Klinikleri J Nurs Sci 2014;6(1):46-53.

26. Asadi P, Ahmadi S, Abdi A, Shareef OH, Mohamadyari T, Miri J. Relationship Between Self-Care Behaviors and Quality of Life in Patients with Heart Failure. Heliyon 2019;5:1-6.

27. Sedlar $\mathrm{N}$ et al. Measuring self-care in patients with heart failure: A review of the psychometric properties of the European Heart Failure Self-Care Behaviour Scale (EHFScBS). Patient Education and Counseling 2017;100(7):1304-1313.

28. Vardar İnkaya B, Oğuz S. Kardiyak Rehabilitasyon. Yoğun Bakım Hemşireliği Dergisi 2010;14(1)14-9. 